\title{
Negotiating cultural, political, and spiritual meaning through affect and movement
}

\section{Lourdes Torres ${ }^{1}$}

Published online: 18 May 2021

( ) The Author(s), under exclusive licence to Springer Nature Limited 2021

We often underestimate the importance of affect and psychology as we focus on our everyday tasks and social justice work. The articles in this issue highlight a variety of strategies Latinx communities take up as they attempt to affirm their place in diverse geographies and wide-ranging contexts while they navigate myriad internal and external tensions. From the salsa studio and the concert hall to the unemployment center to political and spiritual organizing spaces, these articles move us into spaces beyond the surface. Exploring the vitality of dance and music, the embodiment of dolor and rabia, and the power of spirituality and psychology, these essays invite us to witness how the Latinx community engages with the persistent negotiation of cultural, political, and spiritual meaning with feeling, creativity, and ingenuity.

In our lead essay, Carmela Muzio Dormani offers a fascinating glimpse to the on2 salsa dance world in New York. Although some argue that salsa's immense popularity and its subsequent commercialization has meant that it has veered away from its political origins, Muzio Dormani argues that on2 salsa dancers contest and challenge this racialized commodification as they also claim a space for salsa amid the New York gentrified urban environment. Via strategies that center Nuyorican and Afro-Caribbean cultural identity, dancers resist cultural erasure and affirm their right to the city on their own terms.

In another essay focused on the arts, Francisco E. Robles introduces the concept of "moving homelands" to capture the intricate negotiation of belonging and nostalgia in Lydia Mendoza's musical performances. Providing discerning and incisive analysis of some of the legendary Mexican folk singer's poignant songs, recorded at a live concert in California, Robles demonstrates how Mendoza, together with her live audience, enact a visceral experience of communal belonging.

Moving to a context of meaning-making in Puerto Rican politics in the early 2000s, Víctor M. Torres-Vélez considers the emergence of women's anti-military activism in Vieques, Puerto Rico. Torres-Vélez establishes how intense emotions of suffering and

Lourdes Torres

1torres@depaul.edu

1 DePaul University, Chicago, IL, USA 
indignation triggered by the illnesses of their families and friends shaped Puerto Rican women's awareness and activated them to take political action to fight environmental devastation on their island caused by long-term military pollution. Torres-Vélez makes a strong case for the role of affect in the politicization of these fierce feminist warriors who took on the US military-industrial complex.

Turning to another powerful life-shaping resource, Jack Caraves demonstrates how spirituality becomes a pivotal source of strength for trans Latinxs. While religious communities too often reject and demonize people with nonnormative genders and sexualities, Caraves uncovers, via interviews with trans Latinxs in Los Angeles, how trans Latinxs take up and embody a spirituality that includes and nourishes them. Trans Latinxs are proactive and creative in finding spiritual communities that meet their needs. If they can't find a place in conventional Christian or Catholic settings, they seek out other accepting Latinx spaces in nontraditional communities, and if these don't exist, they create their own spiritual homes where they find healing and sustenance.

Rounding out our original articles, Maritza Caicedo, Edwin van Gameren and Catalina Amuedo-Dorantes examine, in their meticulous study, how psychological distress manifests in unemployed and underemployed Latin Americans and Latinos. They compare Mexican and Colombians living in the United States with similarly positioned people in their countries of origin. This study serves to unpack generalizations about the "Hispanic paradox" as it also resists the usual homogenizing of diverse Latinx communities.

We follow up these articles with timely essays about two of our most troubling national challenges. A reflexiones pedagógicas essay by Jesica Siham Fernández foregrounds the current COVID-19 pandemic as a teachable moment. Her Testimoniando El Presente essay assignment encourages students to think and write critically about the experiences of grief, loss, and struggle they and their families are living through, as they also consider the inequities of US public health systems.

We also are proud to share two vivencias essays that capture the hardships visited on our community as the nation continues to stall on addressing current dehumanizing immigration policies. Óscar F. Gil-García, Francesca Bové, Luz Velazquez, Sarah Vener and Alexandra Miranda bring us the heart-wrenching story of a young boy of Indigenous (Acatek) Maya descent who experienced family separation from his undocumented father under this country's inhumane zero-tolerance policy. In the second vivencia, Lizette Solorzano and Paulina Ruiz, two young immigrant youth activists, share how they invoke healing tools from their family and faith backgrounds as they encounter acts of aggression and disrespect while engaging in political activism.

Enjoy!

Publisher's Note Springer Nature remains neutral with regard to jurisdictional claims in published maps and institutional affiliations. 